Cell Research (2003); 13(2):83-91

http://www.cell-research.com

\title{
Cloning and characterization of human IC53-2, a novel CDK5 acti- vator binding protein
}

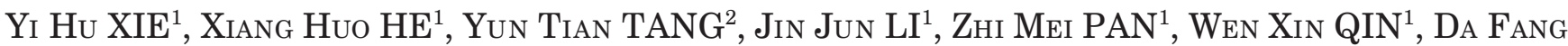 \\ WAN ${ }^{1 *}$, JIAN REN GU ${ }^{1 *}$ \\ ${ }^{1}$ State Key Laboratory of Oncogenes and Related Genes, Shanghai Cancer Institute, Shanghai 200032, China \\ ${ }^{2}$ Peopele's Hospital of Guangxi Zhuang Autonomous Region, Nanning 530021, China
}

\begin{abstract}
We have identified IC53-2, a human homologue of the rat C53 gene from a human placenta cDNA library (GeneBank Accession No.AF217982). IC53-2 can bind to the CDK5 activator p35 by in vitro association assay. IC53-2 is mapped to human chromosome 17q21.31. The IC53-2 transcript is highly expressed in kidney, liver, skeletal muscle and placenta. It is abundantly expressed in SMMC-7721, C-33A, 3AO, A431 and MCF-7 cancer cell lines by RT-PCR assay. Stable transfection of IC53-2 cDNA into the hepatocellular carcinoma SMMC-7721 cell remarkably stimulates its growth in vitro. The above results indicate that IC532 is a novel human gene, which may be involved in the regulation of cell proliferation.
\end{abstract}

Key words: IC53-2, CDK5, p35, hepatocellular carcinoma, proliferation.

\section{INTRODUCTION}

Hepatocellular carcinoma (HCC) is one of the most prevalent malignant diseases worldwide. It is the fifth most common cancer and ranks fourth in mortality rate, behind lung, stomach and colon cancers $[1,2]$. HCC is a leading cause for cancer-related deaths in many countries, mainly in Asia and Africa [3]. HCC has been ranked second cause of cancer death in China since 1990s[4]. It appears to be rising in incidence in the United States and other developed western countries[5]. Although the major viral and environmental risk factors for the development of HCC have been determined, the molecular mechanisms that contribute to tumor progression in hepatocarcinogenesis remain unknown[6]. The proliferation of HCC cells is strictly regulated by many negative or positive mediators. Recently, several tumor suppressor genes have been clarified

* Correspondence: Prof. Da Fang WAN, Jian Ren GU

Tel: 0086-21-64177401 Fax: 0086-21-64177401

E-mail: nlorg@public.sta.net.cn

Received Oct-23-2002 Revised Dec-19-2002 Accepted Jan-9-2003 in some oncogenic pathways. In particular, recent data have highlighted the importance of the p53 and $\mathrm{Rb}$ pathways in mediation of HCC cell proliferation $[7,8]$. There are some regions that display high score of loss of heterozygosity ( $\mathrm{LOH})$ in HCC cells. For example, the $\mathrm{LOH}$ region within chromosome $17 \mathrm{p} 13$. 3 in human HCC in China, and some HCC related genes have been identified from this region[9-11]. Identification of novel molecules that regulate HCC cell proliferation could improve our understanding of the regulatory networks and lead to novel diagnosis and treatment decisions.

The eukaryotic cell cycle is controlled by a family of serine/threonine kinases called cyclin-dependent kinases (CDKs). All family members share greater than $40 \%$ sequence identity, and associate with a cyclin regulatory subunit. Cdc2 kinase in fission yeast is one of the earliest identified CDK genes, which performs rate-limiting functions in both G1/ $\mathrm{S}$ and $\mathrm{G} 2 / \mathrm{M}$ checkpoint transition. In mammalian cells, the homologue of cdc2, CDKs controls the entry of S phase and M phase by differentially inter- 
tially identified by biochemical purification from bovine brain and by virtue of its close sequence homology to human CDK2. CDK5 is a proline-directed kinase that phosphorylates serine or threonine immediately upstream of a proline residue. The best known role for CDK5 is in neuronal cell differentiation. There is also evidence that links CDK5 activity to the regulation of cytoskeleton, axon guidance, membrane transport, synaptic function, dopamine signaling and drug addiction[13].

Like other CDKs, monomeric CDK5 shows no enzymatic activity and requires association with a regulatory partner for activation. The active form of CDK5 was shown to be a heterodimer of CDK5 and a $25 \mathrm{KDa}$ regulatory protein[14]. The regulatory subunit was subsequently shown to be a truncated form of a $35 \mathrm{KDa}$ protein now known as neuronal CDK5 activator, P35[15]. By using the yeast twohybrid screen, several P35-associated proteins were isolated, one of which is C53. Chen et al[16] isolated an isoform of C53 from a human aorta cDNA library, called IC53. In this study, we cloned another isoform of C53 from a human placenta cDNA library, named it as isoform 2 of C53 (IC53-2). The expression of IC53-2 was detected by Northern blot in eight human tissues and RT-PCR in eight cell lines. In vitro association assay indicate that IC53-2 can bind to p35 and p25. A preliminary study showed that IC53-2 protein was able to stimulate the growth of human hepatocellular carcinoma SMMC-7721 cell in vitro. We also discuss here the biological importance of IC53-2.

\section{MATERIALS AND METHODS}

\section{Cloning of full-length IC53-2 cDNA}

A cDNA fragment of 2265bp (bp 564-2828 in Fig 1A) was identified from a human placenta cDNA library by expressed sequence tag (EST) direct sequencing. The cDNA was called PP1553 (GeneBank Accession No. AF217982). By searching the public dbEST, the 5'-UTR (Untranslated Region) of PP1553 is incomplete, we carry out PCR using forward primer (5' GGGCGGGCCACAGTCTCCAGCCT-3', bp1-23 in Fig 1A and F 1 in Fig 1B) and reverse primer (5' TCAACAGAGCACACAACTGACTCTC-3', bp1595-1619 in Fig $1 \mathrm{~A}$ and R1 in Fig 1B) based on the EST contig to get the 5'-UTR of IC53-2.

\section{Sequence analysis}

Homology comparisons between species were performed using
BLAST algorithm through the National Center for Biotechnology Information web server (http://www.ncbi.nlm.nih.gov/BLAST). Multiple sequence alignments were made at http://www.ebi.ac.uk/ clustalw/index.html (Fig 1D).

\section{Northern blot analysis}

Hybridization was carried out on human normal Multiple Tissue Northern Blot membrane (Clontech) as suggested by the manufacturer. The IC53-2 cDNA probe was labeled with $\left[\alpha-{ }^{32} \mathrm{P}\right]$ dCTP by rediprime II random primer labeling system (Amersham Pharmacia Biotech). Northern blot membrane were prehybridized at $68^{\circ} \mathrm{C}$ for $1 \mathrm{~h}$ in ExpressHyb hybridization solution (Clontech) with $0.1 \mu \mathrm{g} / \mathrm{ml}$ denatured and sheared salmon sperm DNA. Then, hybridization was performed at $68^{\circ} \mathrm{C}$ for $2 \mathrm{~h}$ in ExpressHyb hybridization solution plus the specific radiolabelled probes prepared before. Membrane washing and autoradiography were done according to the published methods[17].

\section{In vitro association assay}

cDNA encoding p35, p25 and p10 were subcloned into the eukaryotic expression vector pcDNA3.1/HA2 respectively. They are designated HA2-p35, HA2-p25, HA2-p10. IC53-2 cDNA containing the complete coding sequence (bp 1595-2441) was prepared by PCR and subcloned into the eukaryotic expression vector pcDNA4/HisMax-TOPO (Invitrogen) and verified by sequencing. The following primers were used for PCR amplification: forward primer (5'-A T GCTGCGGTTCGTGCAGAAGCGG-3', bp1595-1618) and reversed primer (5'-TCACAGAGAGGTTCCCATCAGGTTC-3', bp24172441). There is a Xpress Tag on the pcDNA4/ HisMax-TOPO vector, so we designated it as Xpress-IC53-2. The plasmid DNA was extracted and purified with the Qiagen plasmid purification kit. HA2-p35, HA2-p25, HA2-p10 and Xpress-IC53-2 were transcribed and translated in vitro by using the TNT Quick Coupled Transcription/Translation System (Promega, Madison, Wis.) with $\left.{ }^{[55} \mathrm{S}\right]$ methionine (Amersham Pharmacia Biotech) in accordance with the manufacturer's instruction. Then, $10 \mu$ IC53-2 reaction product was mixed with $10 \mu \mathrm{l}$ reaction product of $\mathrm{p} 35, \mathrm{p} 25, \mathrm{p} 10$ respectively. The $20 \mu \mathrm{l}$ reaction product mixture was incubated in TNT buffer (20 mM Tris-HCl, $200 \mathrm{mM} \mathrm{NaCl,} \mathrm{1 \%} \mathrm{Triton} \mathrm{X-100)}$ with anti-Xpress monocolonal antibody (Invitrogen) and $20 \mu \mathrm{l}$ of protein A/G PLUS agarose (Santa Cruz Biotechnology). After incubation at $4^{\circ} \mathrm{C}$ for $2 \mathrm{~h}$, the protein $\mathrm{A} / \mathrm{G}$ PLUS agarose beads were washed three times with $0.6 \mathrm{ml}$ of the TNT buffer. Then, the proteins were solubilized in sodium dodecyl sulfate (SDS) sample buffer, subjected to SDS/12\% PAGE, and visualized by autoradiography.

\section{Cell culture}

Eight cell lines were used in the study: human hepatocellular carcinoma cell line SMMC-7721, human normal hepatocyte cell line L-02, human umbilical vein endothelial cell-derived cell line ECV304, human epithelial cervix carcinoma cell line C-33A, human cervix carcinoma cell line HeLa, human ovary adenocarcinoma cell line 3AO, human epidermoid carcinoma cell line A431 
and human breast adenocarcinoma cell line MCF-7. These cells were incubated in $5 \% \mathrm{CO}_{2}$ at $37^{\circ} \mathrm{C}$ and cultured in DMEM (Dulbecco's Modified Eagle Medium) with 10\% fetal bovine serum (GibcoBRL), $100 \mu \mathrm{g} / \mathrm{ml}$ penicillin, and $100 \mu \mathrm{g} / \mathrm{ml}$ streptomycin sulfate.

\section{RNA isolation and RT-PCR analysis}

Total RNA from $10^{7}$ cells was extracted using the Trizol reagent (GibcoBRL) and treated with DNase I (TaKaRa). RNA quality was checked by electrophoresis in $1.5 \%$ agarose/formaldehyde denaturing gel. cDNA was prepared from $5 \mu \mathrm{g}$ total RNA, using the SuperScript II reverse trancriptase suggested by the vender (GibcoBRL). The IC53-2 cDNA was amplified with Taq DNA polymerase (Shanghai Promega). The forward primer (5'-CGATGAGGGTTGGATTAGA-3', bp911-929 in Fig 1A and F2 in Fig 1B) and the reversed primer (5'TCAACAGAGCACACAACTGACTCTC-3', bp1595-1619 in Fig $1 \mathrm{~A}$ and $\mathrm{R} 1$ in Fig 1B) were designed from the specific sequence of human IC53-2 gene (PCR product size 709bp); The expression of $\beta$-actin was analyzed as a control with forward primer (5'GGACTTCGAGCAAGAGATGG-3') and reversed primer (5'AGCACTGTGTTGGCGTACAG-3'). The size of PCR product is $214 \mathrm{bp}$. The following PCR cycling parameters were employed: $94^{\circ} \mathrm{C}$ for $5 \mathrm{~min}$; followed by 35 cycles at $94^{\circ} \mathrm{C}$ for $30 \mathrm{~s}, 60^{\circ} \mathrm{C}$ for 30 $\mathrm{s}$, and $72^{\circ} \mathrm{C}$ for $45 \mathrm{~s}$; then $72^{\circ} \mathrm{C}$ for $10 \mathrm{~min}$. The PCR products of IC53- 2 and $\beta$-actin were then resolved on a $2 \%$ agarose gel.

\section{Transfection}

HCC SMMC-7721 cells grown in a $35 \mathrm{~mm}$ cell culture dish (CORNING) were transfected with pcDNA4/HisMax-TOPO-IC532 plasmid DNA or pcDNA4/HisMax-TOPO empty vector DNA by means of LipofectAMINE in conditions recommended by the manufacturer (Invitrogen). Plasmid DNA ( $1 \mu \mathrm{g})$ was dissolved in $100 \mu \mathrm{l}$ medium without serum and mixed with $10 \mu \mathrm{l}$ LipofectAMINE reagent dissolved in $100 \mu \mathrm{l}$ serum-free media, and incubated at room temperature for $30 \mathrm{~min}$ to allow DNAliposome complexes to form. Then, $800 \mu \mathrm{l}$ serum-free medium was added, and the DNA-liposome solution was applied onto a monolayer of $5 \times 10^{4} \mathrm{SMMC}-7721$ cells in $35 \mathrm{~mm}$ cell culture dish. The cells were incubated with the complexes for $5 \mathrm{~h}$ at $37^{\circ} \mathrm{C}$ in a $\mathrm{CO}_{2}$ incubator. Following incubation, $1 \mathrm{ml}$ of growth medium containing twice the normal concentration of serum was added without removing the transfection mixture. $19 \mathrm{~h}$ later, the medium was removed and the cells were supplied with fresh, complete medium containing $100 \mu \mathrm{g} / \mathrm{ml}$ Zeocin (Invitrogen) to select the stable clones.

\section{Cell proliferation assay}

SMMC-7721 cells were plated into flat-bottomed 96-well plates at a density of $1.0 \times 10^{3}$ cells $/$ well. The cells were cultured for 6 days ( 1 day as a time-point), and the proliferation was determined by a MTS 3-(4, 5-dimethylthiazol-2-yl)-5-(3-carboxymethoxyphenyl)2-(4-sulfophenyl)- 2H-tetrazolium, inner salt.) assay using CellTiter $96 \mathrm{AQ}_{\text {ueous }}$ One Solution Cell Proliferation Assay Kit (Promega). $20 \mu \mathrm{l}$ of MTS reagent was added into each well of the
96 well assay plate containing the samples in $100 \mathrm{ml}$ of cultured medium and incubated for $1 \mathrm{~h}$ at $37^{\circ} \mathrm{C}$ in a humidified, $5 \% \mathrm{CO}_{2}$ atmosphere. The absorbance at $490 \mathrm{~nm}$ was read using a Model550 ELISA plate reader (Bio-Rad). A growth curve with the absorbance of the MTS assay for the conversion of MTS to formazan was directly correlated with the number of living cells in culture. The experiment was triplicate-performed independently.

\section{Immunoblots}

SDS-polyacrylamide gel electrophoresis was performed in $12 \%$ vertical slab gels. For western blot analyses, $30 \mu \mathrm{g}$ total protein was loaded into each lane. After electrophoresis, proteins were transferred to PROTRAN nitrocellulose transfer membrane (Schleicher and Schuell). The blots were probed with a 1/2000 dilution of Anti-Xpress primary antibody (Invitrogen), followed by incubation with a 1/2000 dilution of the goat anti-mouse IgG conjugated with horseradish peroxidase (Santa Cruz Biotechnology) and detected with SuperSignal West Femto Maximum Sensitivity Substrate (Pierce).

\section{RESULTS}

\section{Cloning and identification of IC53-2}

Using expressed sequence tag direct sequencing, we identified a human placenta cDNA clone, PP1553 (Length: 2265bp, bp 564-2828 in Fig 1A, GeneBank Accession No. AF217982). By searching the NCBI dbEST and human genome database, the 5'- UTR of PP1553 is incomplete, we carry out PCR using forward primer (bp1-23 in Fig 1A and F1 in Fig 1B) and reverse primer (bp1595-1619 in Fig 1A and R1 in Fig 1B) based on the EST contig and get the extended 5'-UTR, full length cDNA is 2828bp. Database searches indicated that the predicted protein is $56 \%$ and $67 \%$ identity to human C53 and IC53 (Fig 1B and Fig 1D) respectively. To distinguish it from IC53, we called it IC53-2. IC53-2 has two insert sequences of $710 \mathrm{bp}$ (bp 378-1087 in Fig 1A and Fig 1B) and 215bp (bp 1407-1621 in Fig 1A and Fig 1B), compared with that of human C53. There is a stop codon (bp 1617-1619) upstream of the ATG start codon (bp 1644-1646). The polyadenylation signal AATAAA is present at bp 2738 to 2743 (Fig 1A).

The full-length cDNA of IC53-2 encodes a protein with 281 amino acids. The IC53-2 protein contains one consensus phosphorylation site for CDK5 (bp 2244-2249, Fig 1A, shown in bold), which is a serine or threonine followed by a proline residue.

IC53-2 was mapped to chromosome 17q21.31 
with 12 exons and spans a region about $11.3 \mathrm{~Kb}$ (Fig 1B). The exon-intron junctions matched the GT-AG rulBy accessing the GeneBank database for fulllength cDNAs, we found that IC53-2 had the highest sequence identity to the human C53, human IC53, rat C53, mouse C53, C.elegens C53, and fruit fly C53 (Fig 1D).

\section{Expression patterns of IC53-2}

We examined the tissue expression pattern of IC53-2 by hybridizing its cDNA probe (bp 564-2272, Fig 1A) on a multiple-tissue northern blot (MTN, Clontech). We detected two transcripts of 2.0 and 3. $0 \mathrm{~Kb}$ in all eight normal tissues (Fig 2A).

The presence of two hybridized bands suggests that at least two isoforms exist. To confirm which

A

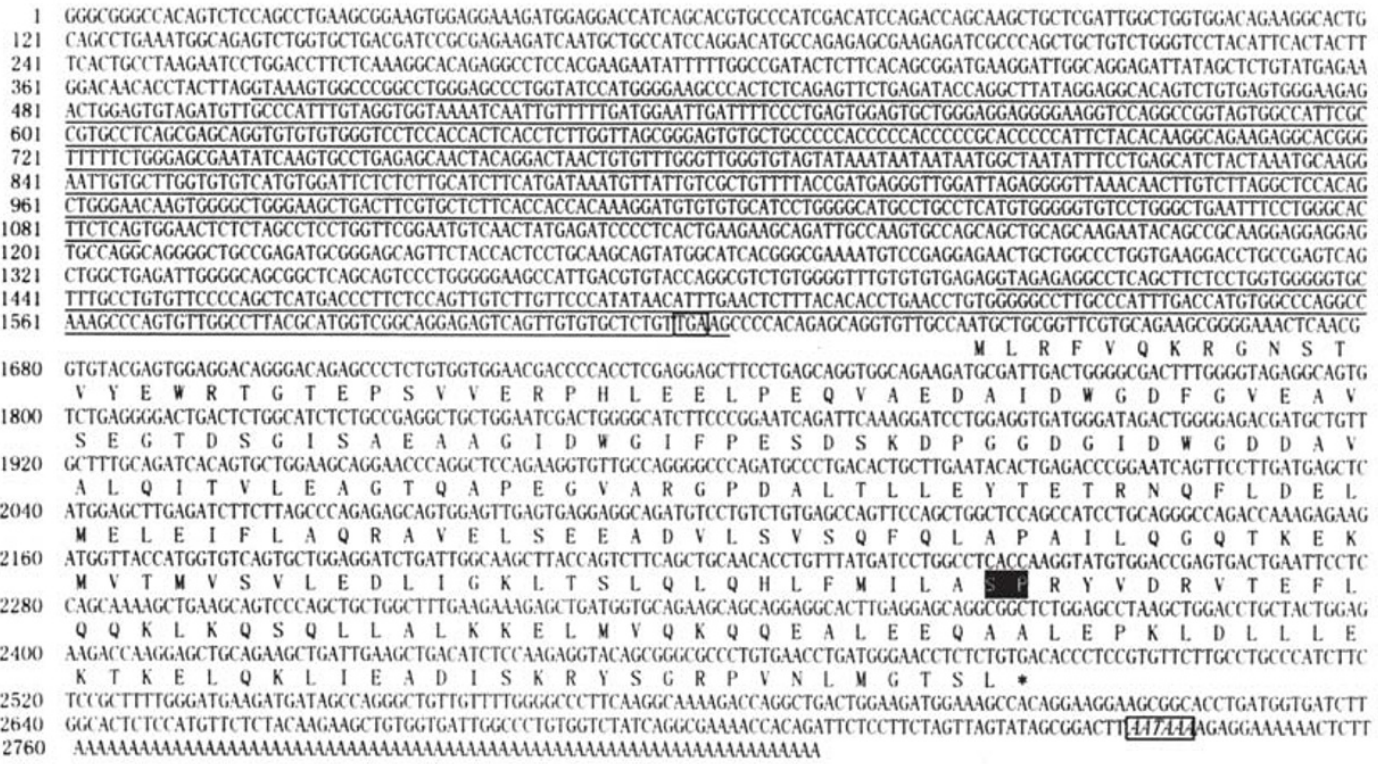

B

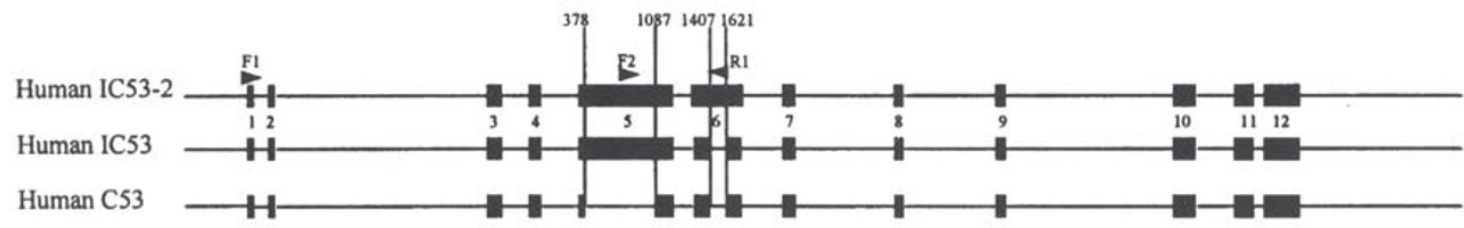

C

\begin{tabular}{|c|c|c|c|c|}
\hline Gene ID & $\begin{array}{l}\text { Exon No } \\
\text { /size(bp) }\end{array}$ & 5'Splice donor & $\begin{array}{l}\text { Intron No } \\
\text { /size(bp) }\end{array}$ & 3'Splicer acceptor \\
\hline IC53-2 & $\begin{array}{l}\text { Ex.1(49) } \\
\text { Ex.2(46) } \\
\text { Ex.3(132) } \\
\text { Ex.4(101) } \\
\text { Ex.5(938) } \\
\text { Ex.6(500) } \\
\text { Ex.7(111) } \\
\text { Ex.8(79) } \\
\text { Ex.9(89) } \\
\text { Ex.10(206) } \\
\text { Ex.11(172) } \\
\text { Ex.12(336) }\end{array}$ & $\begin{array}{l}\text { AAGATGGAGgtgtgggga } \\
\text { AGCTGCTCGgtaggaggg } \\
\text { CTGGGTCCTgtgagtgct } \\
\text { CGGATGAAGgcaagtgtg } \\
\text { GGCATCACGgtgagcgge } \\
\text { GAAGATGCG CAagatgg } \\
\text { GATTCAAAGgtgaggagg } \\
\text { GAACCCAGGgtaagtgca } \\
\text { CTCATGGAGgtactgtca } \\
\text { CTCACCAAGgtctggctt } \\
\text { CAGAAGCTGgtgagatgg }\end{array}$ & $\begin{array}{l}\text { In.1(209) } \\
\text { In.2(2113) } \\
\text { In.3(280) } \\
\text { In.4(366) } \\
\text { In.5(176) } \\
\text { In.6(698) } \\
\text { In.7(1009) } \\
\text { In.8(920) } \\
\text { In.9(1675) } \\
\text { In.10(364) } \\
\text { In.11(102) }\end{array}$ & $\begin{array}{l}\text { tcccgccagGACCATCAG } \\
\text { ctcatgtagATTGGCTGG } \\
\text { gcttctagACATTCACT } \\
\text { cttactcagGATTGGCAG } \\
\text { cctctctagGGCGAAAAT } \\
\text { ccttccagATTGACTGG } \\
\text { tccttccagGATCCTGGA } \\
\text { tcctggcagCTCCAGAAG } \\
\text { tgtcctcagCTTGAGATC } \\
\text { cccgcacagGTATGTGGA } \\
\text { ctcttcagATTGAAGCT }\end{array}$ \\
\hline
\end{tabular}




\begin{tabular}{|c|c|c|c|}
\hline $\begin{array}{l}\text { Human IC53 } \\
\text { Human IC53 }\end{array}$ & $3-$ & - & \\
\hline Human C53 & & MEDHQHVP IDIQTSKLLDWLVDRRHCSLKWQSLVLT IREK INAA IQDMPESEEIAQLLSG & 60 \\
\hline Rat $\mathrm{C} 53$ & & MQDHQHVP IDIQTSKLLDWLVDRRHCNLKWQSLVLT IREK INTA I QDMPESQE I AQLLSG & 60 \\
\hline Mouse C53 & & MQDHQHVPIDIQTSKLLDWLVDRRHCNLKWQSLVLT IREK INTA IQDMPESQEI AQLLSG & 60 \\
\hline C. elegens & C53 & --MSDDLPIDIHSSKLLDWLVSRRHCNKDWQKSVVA IREK IKHA ILDMPESPK IVELLQG & 58 \\
\hline Fruit fly & C53 & -MNESEIPIDIHTLKLQDWLISRRIVPKNVQQELREIHRK ISNALQDMPSNEQLIKLLAR & 59 \\
\hline Human IC53 & & & \\
\hline Human IC53 & & ----MCVHPGACLPHVGVSWAEFPGHFS-- - - & \\
\hline Human C53 & & SY IHYFHCLR I LDLLKGTEASTKNIFGRYSSQRMKDWQEI I ALYEKDNTYLVELSSLLVR & 120 \\
\hline Rat C53 & & SY IHYFHCLR I VDLLKGTEASTKNIFGRYSSQRMKDWQEI I & 120 \\
\hline Mouse C53 & & SY IHYFHCLR IVDLLKGTEASTKNIFGRYSSQRMKDW & 120 \\
\hline C. elegens & C53 & AY INYFHCCQ I IEI LRDTEKDTKNFLGFYSSQRMKDWQE IEGMYKKDNVYLAEAAQILQR & 118 \\
\hline Fruit fly & C53 & TNINYYHVKEI IEILKQTEKDTKSVFGTYGSQRMKDWQEISRLYEKNATYLAETAQIFVR & 119 \\
\hline Human IC53 & & & \\
\hline Human IC53 & & NVNYE IPSLKKQIAKCQQLQQEYSRKEEECQAGAAEMREQFYHSCKQYG ITGENVRGELL & 93 \\
\hline Human C53 & & JVNYEIPSLKKQIAKCQQLQQEYSRKEEECQAGAAE & 30 \\
\hline Mouse C53 & & IVSYEIPSLKKQIAKCQQLQQEYSRKEEEGQAGAAEMREQFYHSCKQYGITGDNVRRELL & 180 \\
\hline C. elegens & C53 & LAQYEIPALRKQISKMDQSVTDAIRKHSEYGKQAEDGRKQFEKEISRMQLKGVHLRKFJL & 178 \\
\hline Fruit fly & C53 & NVNYEIPGVRKQMARLEQQADETQKRAHDLNKPESQILADHSALLEQLGVKGDNLHAEIVV & 179 \\
\hline Human IC53 & $3-2$ & - MLRFVQKRG-N & 10 \\
\hline Human IC53 & & ALVKI & 148 \\
\hline Human C53 & & LVKDLPSQLAEIGAAAQQSLGEAIDVYQASVGFVCESPT----E & 235 \\
\hline Rat C53 & & LVKDLPSQLAEIGAGAQS-LGEA IDLYQACVEFVCDSPT----EQVLPMLRYVQPKG-N & 234 \\
\hline Mouse C53 & & IDLYQACVEFVCDSPT---EQVLPMLRYVQKKG-N & 234 \\
\hline C. elegens & C53 & IRK-ISAARDYFQAFRDYMSLGAAPKDAAP ILPI IGLIGERGLD & 237 \\
\hline Fruit fly & C53 & QVLSGLPELYDKSLVGIAN-IQPGIDLYAEVSGNK-- & 227 \\
\hline Human IC53 & & & \\
\hline Human IC53 & & $\begin{array}{l}\text { DW } \\
\text { DW }\end{array}$ & 6 \\
\hline Human C53 & & STVYEWRTGTEPSVVERPHLEELPEQVAE-DAIDWGDFGVEAVSE & 294 \\
\hline Rat $\mathrm{C} 53$ & & STVYEWRTGTEPSVVERPQLEDPPEQVQE-DE IDWGDFGLEAVSDSGN I - ISAETPG IDW & 292 \\
\hline Mouse C53 & & STVYEWRTGTEPSVVERPQLEEPPEQVQE-DEIDWGDFGVEAVSDSG--IVAETPG IDW & 290 \\
\hline C. elegens & C53 & VTTYEWKYNQKPDKVEKPNFEMLLTAAEDSDEIDFGGG------- DEIDF & 280 \\
\hline Fruit fly & C53 & TTVYQY IHKEAPLAVEEPP I RLNLSEGNASKDDNAVAEIDFGTDDNGGTSSTVSAE I I DY & 287 \\
\hline & & *. *:: $\quad * \quad * *, *$ : $\quad * \quad$ : & \\
\hline $\begin{array}{l}\text { Human IC53 } \\
\text { Human IC53 }\end{array}$ & $3-2$ & G IFPESDSKDPGGDG IDWGDD-AVALQITV-----------LEAGTQAPEGVARGPDALT & 117 \\
\hline $\begin{array}{l}\text { Human } \\
\text { Human } \mathrm{IC5} 3\end{array}$ & & $\begin{array}{l}\text { GIFPESDSKDPGGDG IDWGDD-AVALQITV--- } \\
\text { GIFPESDSKDPGGDGIDWGDD-AVALQITV- }\end{array}$ & 255 \\
\hline Rat C53 & & GISLESESKDAGADKIDWGDN-AVASEITV- & 340 \\
\hline Mouse C53 & & G ISLESEAKDAGADK IDWGDDAAAASEITV- - LETGTEAPEGVARGSDALT & 339 \\
\hline C. elegens & C53 & G IAAEDDAVIDFSAVVDLVAD-- - DTGAVG-EAIASGQDALH & 318 \\
\hline Fruit fly & C53 & DAVEINFD IPVEEYG IVVEGTGMDGGTAKGDQAYT & 347 \\
\hline & & $: * \quad: \quad: \quad:$ & \\
\hline Human IC53 & $3-2$ & LLEYTETRNQFLDELMELEIFLAQRA & 176 \\
\hline Human IC53 & & LEYTETRNQFLDELMELEIFLAQ & \\
\hline Human C53 & & LEYTETRNQFLDELMELEIFLAQR & \\
\hline Rat C53 & & LLEYPETRNQF IDELMELE IFLSQRAVEMS-EEADI LSVSQFQLAPA ILQGQT & 399 \\
\hline Mouse C53 & & LLEYPETRNQF IDELMELEIFLSQRAVEMS-EEADILSVSQFQLAPA I LQGQTKEKMLSL & 398 \\
\hline C. elegens & C53 & LENSEAQKAVKHELIELLAFLSMRLDDETRETTADVLIRGAEKRPDGVAAVTEKRLKTW & 378 \\
\hline Fruit fly & C53 & LLDSPNYRDRFLDEIYELESFLRMR I YELKQLESSSDIMFSLMDN---IATHDGES I WK I & \\
\hline & & $* *: .:: . . . * *$ : * * * * * : : : & \\
\hline Human IC53 & $3-2$ & VSVLEDLIGKLTSILQLQHLFM I LASPRYVDRVTEFLQQKLKQSQLLALKKELMVQKQQEA & 236 \\
\hline $\begin{array}{l}\text { Human }{ }_{\text {Human }} \text { C553 } \\
\text { Huma }\end{array}$ & & & \\
\hline $\begin{array}{l}\text { Human C53 } \\
\text { Rat C53 }\end{array}$ & & SVLEDLIGKLTSLQLQHLFM ILASPRYVDRVTEFLQQKLKQSQLLALKKELMV & \\
\hline $\begin{array}{l}\text { Rat C53 } \\
\text { Mouse C53 }\end{array}$ & & $\begin{array}{l}\text { VSTLQHLIGQLTSLDLQHLFM ILASPRYVDRVTELLQQKLKQSQLL. } \\
\text { VSTLQQLIGRLTSLRMQHLFMILASPRYVDRVTEFLQQKLKQSQLL }\end{array}$ & $\begin{array}{l}459 \\
458\end{array}$ \\
\hline C. elegens & C53 & ITEVEG ILKELENPQK VHLFK IRGSPQYVEQVVEELEKKRDMEHRYKRLQTLMTENQETA & 438 \\
\hline Fruit fly & & LVSVEK I IQQTSDKQTQHLFQLKHSPKYANMLATKLQQMTKAVEKLRATREALKQLTIEL & 464 \\
\hline & & . $\quad * * *: \quad * *: * .: \quad: \quad *:: \quad \cdot \quad \cdot \quad: \quad:$ & \\
\hline & $3-2$ & LEEQAALEPKLDLLLEKTKELQKLIEADISKRYSGRPVNLMG---TSL--- 281 & \\
\hline $\begin{array}{l}\text { Human } \\
\text { Human } \\
\text { C } 53\end{array}$ & & LEEQAALEPKLDLLLEKTKELQKLIEADISKRYSGRPVNLMG---TSL--- 419 & \\
\hline $\begin{array}{l}\text { Human C53 } \\
\text { Rat C53 }\end{array}$ & & $\begin{array}{l}\text { LEEQAALEPKLDLLLEKTKELQKLIEADISKRYSGRPVNLMG---TSL--- } 506 \\
\text { LQEQAALEPKLDLLLEKTRELQKLIEADISKRYNGRPVNLMG---TSV-- } 504\end{array}$ & \\
\hline Mouse C53 & & LQEQAALEPKLDLLLEKTRELQKLIEADISKRYSGRPVNLMG---TSL-- 503 & \\
\hline C. elegens & C53 & RQSVTKSNVELKT IVESTRVLQKQIEAEISKKYNGRRVNLMGG INQALGGN 489 & \\
\hline Fruit fly & C53 & REQRQDLNPVLEELIAQTRTLQSHIEKDISKRYKNRVVNLMG---GVN-- 509 & \\
\hline & & $\therefore \quad$ : $\quad * . \quad::$ : *: **. ** :***:*..,******* . : & \\
\hline
\end{tabular}

Fig 1 Nucleotide and amino acid sequences analysis of IC53-2. A. Nucleotide sequence of human IC53-2 cDNA and its deduced amino acid sequence. The underlined letters indicate the insert sequence compared with C53 and IC53 (bp 378-1087 and bp 1407-1621). B. Genomic structure of three transcripts of the human IC53-2, IC53 and C53 genes. Blank box indicate the exon. IC53-2 has two insert sequences of $710 \mathrm{bp}$ (from bp 378 to 1087) and 215bp (from bp 1407 to 1621), compared with that of human C53 . C. Exon-intron organization of the human IC53-2. (Exon/intron size and nucleotide sequence at the exon and intron boundaries are given) D. Amino acid alignment of IC53-2 homologues of various organisms, by clustal w program. The consensus line: “*” indicates identical or conserved residues in all sequences in the alignment; ":” indicates conserved substitutions; "." indicates semiconserved substitutions. 


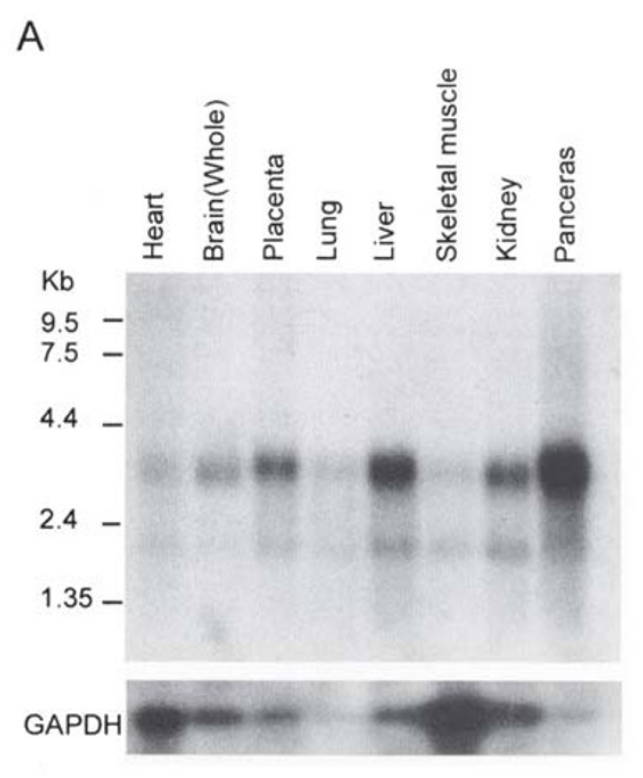

B
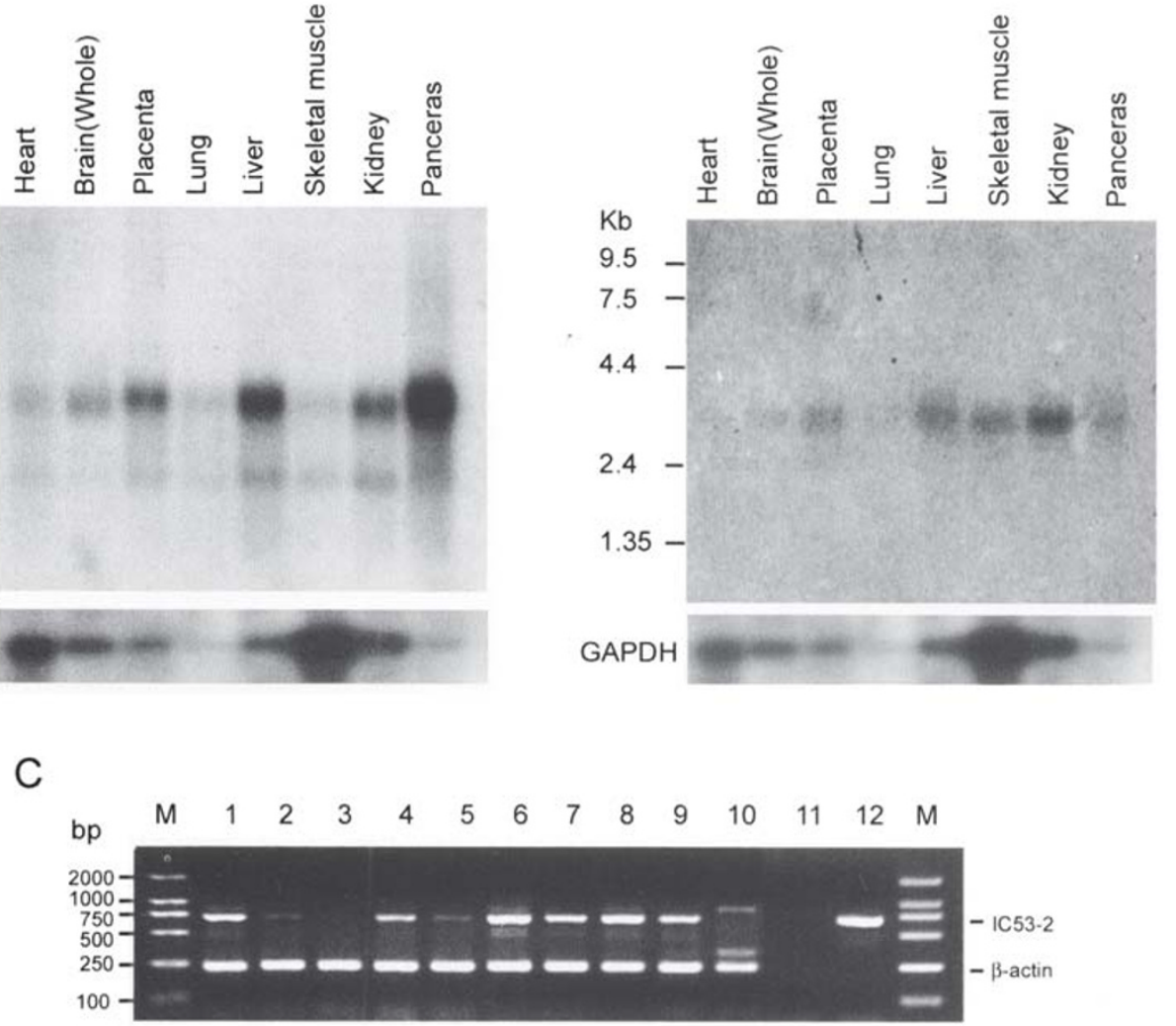

Fig 2. Tissue distribution of human IC53-2. A. Northern blot analysis using a human multiple tissue northern blot containing $2 \mu \mathrm{g}$ poly $\mathrm{A}^{+} \mathrm{RNA}$ from different human tissues in each lane. GAPDH was used to evaluate the loading of mRNA. cDNA fragment of IC53-2 (bp 564-2828) was used as probe. B. IC53-2 specific insert of 215bp (bp 1407-1621) was used as probe to hybridize with MTN. C. Expression of human IC53-2 gene (709bp) in eight cell lines were analyzed by RT-PCR, SMMC-7721 (lane 1), L-02 (lane 2), ECV304 (lane 3), C-33A (lane 4), Hela (lane 5), 3AO (lane 6), A431 (lane 7), MCF-7 (lane 8). Human placenta cDNA (lane 9) and human normal liver genomic DNA (lane 10, 886bp). pcDNA4/HisMax vector was used as negative control (lane 11) and pcDNA4/HisMax-IC53-2 as positive control (lane 12). $\beta$-actin was used as a loading control (214 bp).

transcript is the full-length cDNA of IC53-2, we use the specific sequence of IC53-2 (bp 1407-1621, Fig $1 \mathrm{~A}$ and Fig 1B) as a probe to perform Northern blot hybridization on a MTN blot membrane. Only 3-Kb transcript was detected (Fig 2B). The IC53-2 transcript is highly expressed in kidney, liver, skeletal muscle and placenta.

We used specific primer of IC53-2 (forward primer: bp911-929 in Fig 1A and F2 in Fig 1B; reverse primer: bp1595-1619 in Fig 1A and R1 in Fig 1B) to examine its expression in eight cell lines by semi-quantitative reverse transcription polymerase chain reaction (RT-PCR), with $\beta$-actin as a control. Cell culture and RNA isolation were described previously. Expression of IC53-2 was detected in all cell lines and the expression level was high in hepatocellular carcinoma (HCC) SMMC-7721 cell line, human epithelial cervix carcinoma cell line C-33A, human ovary adenocarcinoma $3 \mathrm{AO}$, human epidermoid carcinoma cell line A431 and human breast adenocarcinoma MCF-7, but the expression level was low in human normal hepatocyte L-02, human umbilical vein endothelial cell-derived ECV304 and human cervix carcinoma HeLa cell lines.

\section{IC53-2 interaction with $p 35$ and p25 in vitro}

In previous study[12], C53 can interact with p35 through yeast two-hybrid assay. To further charac- 
terize the interaction between p35 and IC53-2, the $\mathrm{N}$-terminal (p10) and C-terminal (p25) regions of p35 were tested for their ability to bind to IC53-2. We found that IC53-2 interacted with the fragment encoding the $\mathrm{C}$-terminal p25 protein and not the $\mathrm{N}$ terminal region p10 (Fig 3).

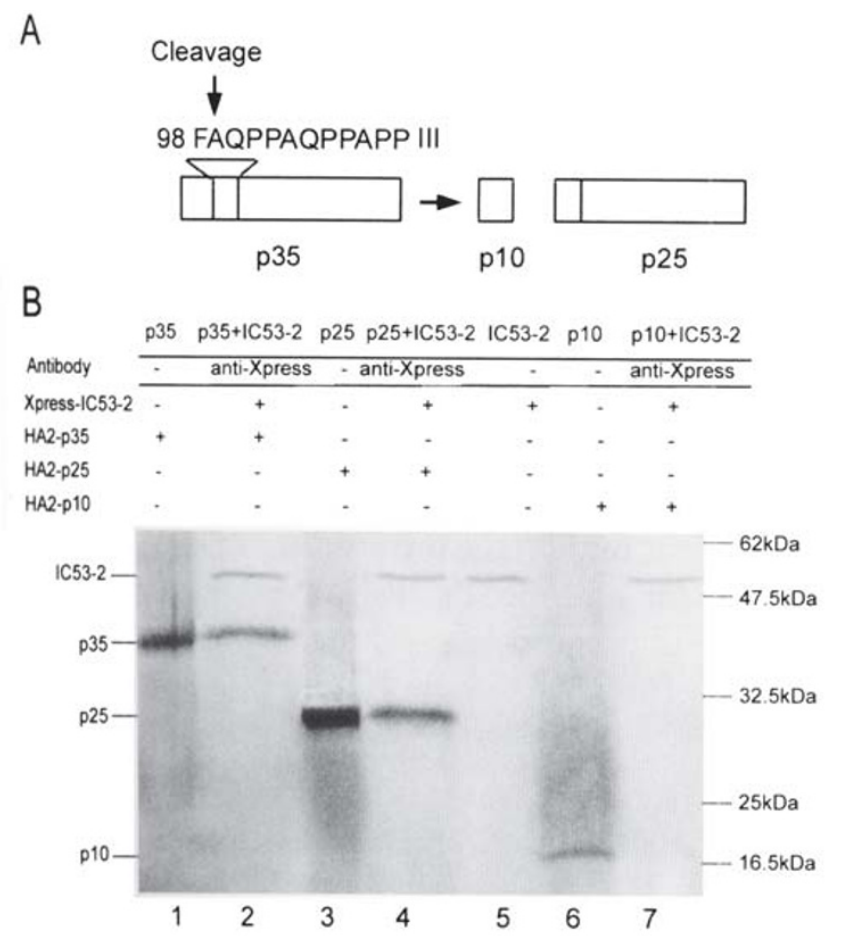

Fig 3. Interaction between IC53-2 and p35. A. The CDK5 activator p35. Proteolytic cleavage of p35 between residues 98 and 99 liberates the C-terminal fragment termed p25 and the N-terminal p10. B. IC53-2 interaction with p35 and p25 but not p10 in vitro. IC53-2 (lane 5), p35 (lane 1), p25 (lane 3), p10 (lane 6) were expressed by an in vitro transcription and translation reaction. Then IC53-2 was mixed with p35 (lane 2), p25 (lane 4), p10 (lane 7), followed by immunoprecipitation with anti-Xpress antibody. The protein-antibody complexes were incubated with protein A/G PLUS agarose beads, washed extensively, and boiled in SDS sample buffer. The eluted proteins were fractionated by SDS-PAGE and then subjected to autoradiograph. Molecular masses (in $\mathrm{KDa})$ are indicated on the right.

Overexpressin of IC53-2 can stimulate the growth of hepatocellular carcinoma SMMC-7721 cells

From our RT-PCR assay, we detected IC53-2 was highly expressed in SMMC-7721 cells. To characterize the effect of overexpression of IC53-2 on cell growth, we constructed stable cell lines by trans- fecting IC53-2 into hepatocellular carcinoma (HCC) SMMC-7721 cells. We used immunoblot to detect the expression of IC53-2 in cells transfected with pcDNA4/HisMax-IC53-2, pcDNA4/HisMax empty vector and SMMC-7721 cells with anti-Xpress primary antibody (Fig 4B). We could see that IC53-2 was overexpressed in the cells transfected with pcDNA4/HisMax-IC53-2. The cell growth curve revealed that the cells transfected with IC53-2 cDNA had a much higher proliferating rate compared with empty vector controls $(\mathrm{p}<0.05)$. The results were reproducible and indicated that IC53-2 was able to stimulate the growth of the cancer cells.

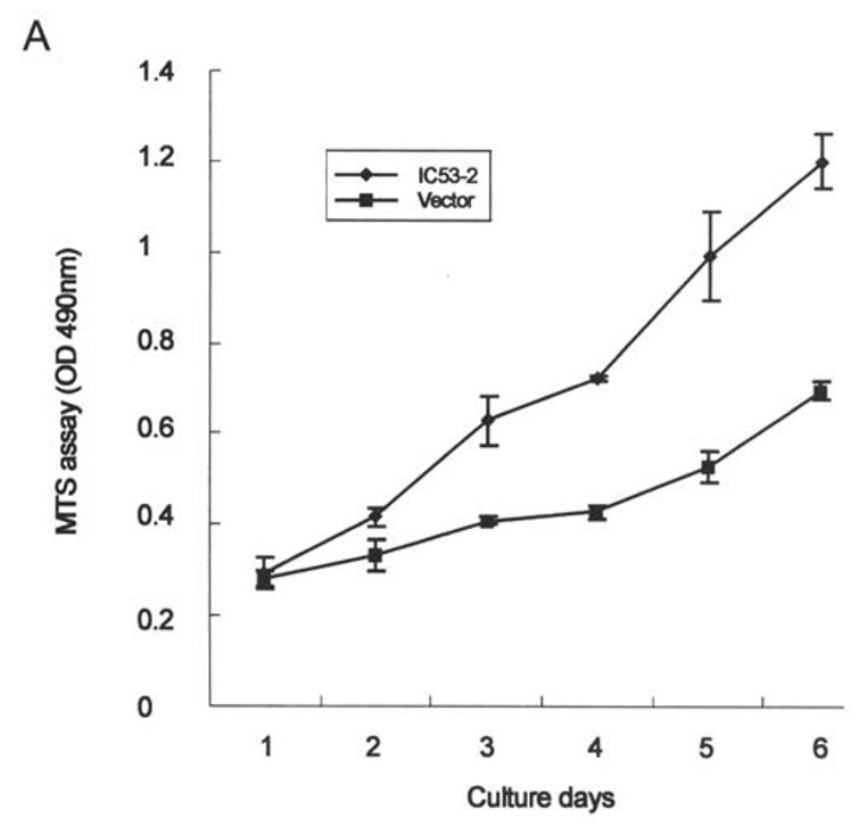

B

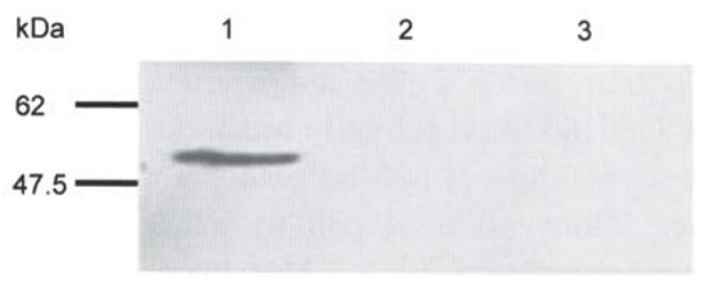

Fig 4. Cell proliferation assay of IC53-2. A. Cell proliferation assay of transfected HCC SMMC-7721 cells. The cell growth was examined everyday for a period of 6 days after plating. The results are means \pm SD in triplicate. B. SMMC-7721 cells transfected with IC53-2 were assayed by western blot using anti-Xpress primary antibody (lane 1). SMMC-7721 cells transfected with empty vector (lane 2) and SMMC-7721 cell (lane 3) were assayed as control. 


\section{DISCUSSION}

In this study, we have cloned and characterized IC53-2, a previously unknown human homologue of rat C53 distinct from the human C53 and IC53. IC53-2, C53 and IC53 are different splicing isoforms which are mapped to $17 \mathrm{q} 21.31$. The detail genomic structures of the three isoforms are indicated in Fig 1B. IC53-2, C53, IC53 full-length cDNA had 2828bp, $1841 \mathrm{bp}$ or 2538bp encoding 281aa, 506aa and 419aa respectively. IC53-2 mRNA is expressed in all tested cell lines and tissues and overexpressed in some tumor cell lines, such as epithelial-like hepatocellular carcinoma SMMC-7721. This result provides a clue linking the gene to the regulation of some cancer cell growth.

To determine the effects of IC53-2 on hepatocellular carcinoma cells, we transfected IC53-2 cDNA into the human SMMC-7721 cells and found that over-expression of IC53-2 can remarkably stimulate SMMC-7721 cell growth. Overexpression of IC53-2 was tested in immunoblot. Chen et al[16] detected stable transfection of IC53 stimulates ECV304 cell proliferation by 2.1-fold compared to cells with empty vector. So IC53-2 and IC53 may have similar function in different tissues. In this study, we have identified high expression of IC53-2 in some tumor cells. IC53-2 is able to stimulate SMMC-7721 cell proliferation in vitro. So, we speculated high expression of IC53-2 have positive effect on liver cancer cell growth. This paper is the first to report the overexpression and the function of human IC53-2 in human HCC cells. Our data suggest that increased expression of IC53-2 may play a role in multistage carcinogenesis.

The $\mathrm{p} 25$ protein is a cleavage product of p35 that activates CDK5 kinase robustly but lacks the aminoterminal 98 residues of p35 necessary for membrane targeting. Conversion of p35 to p25 causes prolonged activation of CDK5. Moreover, expression of p25/ CDK5 complex in cultured primary neurons induces cytoskeletal disruption and apoptosis[18]. IC53-2 can bind to the fragment encoding the C-terminal p25 protein and not the $\mathrm{N}$-terminal region $\mathrm{p} 10$. IC53-2 and its isoforms may co-localize with CDK5 in the cells through their association with p25. Our results suggested that the interaction between IC532 and p25 may regulate the formation of the p25/
CDK5 macromolecular complex, then negatively regulate the kinase activity of p25/CDK5 and inhibit the apoptosis of cells. During evolution, protein primary sequences and structures are often better conserved across species than nucleotide sequences[19]. The high degree of conservation indicates that IC53-2 may play a role in an evolutionarily conserved pathway.

In conclusion, our results indicated that IC53-2 can interact with the C-terminal of p35 and may play a role in regulating the activity of p25/CDK5 kinase. Overexpression of IC53-2 may contribute to the liver cancer cell growth and lead to some pathological conditions in live cancer. Manipulation of IC53-2 would have some clinical relevance to diagnose and treat liver cancer. The molecular mechanism of the growth-stimulating effect of IC53-2 on $\mathrm{HCC}$ cells remains to be elucidated. Moreover, studies aiming at finding the involvement of known signal transduction pathways in such growth regulation are currently in progress.

\section{ACKNOWLEDGEMENTS}

This work was supported by grants (G1998051004, and 2002CB513100) from the China State Key Basic Research Program (to DF WAN, and to WX QIN), and grants (2001AA221141, 2002BA711A02) from the National 863 High Technology Research and Development Program of China (to WX QIN).

\section{REFERENCES}

1. Parkin DM, Pisani P, Ferlay J. Global cancer statistics. CA Cancer J Clin 1999; 49:33-64.

2. Pisani P, Parkin DM, Bray F, Ferlay J. Estimates of the worldwide mortality from 25 cancers in 1990. Int J Cancer 1999; 83:18-29.

3. Di Bisceglie AM, Rustgi VK, Hoofnagle JH, Dusheiko GM, Lotze MT. NIH conference. Hepatocellular carcinoma. Ann Intern Med 1988; 108:390-401.

4. Tang ZY, Yu YQ, Zhou XD, Ma ZC, Wu ZQ. Progress and prospects in hepatocellular carcinoma surgery. Ann Chir 1998; 52:558-63.

5. Befeler AS, Di Bisceglie AM. Hepatocellular carcinoma: diagnosis and treatment. Gastroenterology 2002; 122: 1609-19.

6. Buendia MA. Genetics of hepatocellular carcinoma. Semin Cancer Biol 2000; 10:185-200.

7. Murakami Y, Hayashi K, Hirohashi S, Sekiya T. Aberrations of the tumor suppressor p53 and retinoblastoma 
genes in human hepatocellular carcinomas. Cancer Res 1991; 51:5520-5.

8. Zhang X, Xu HJ, Murakami Y, Sachse R, Yashima K, Hirohashi S, Hu SX, Benedict WF, Sekiya T. Deletions of chromosome 13q, mutations in Retinoblastoma 1, and retinoblastoma protein state in human hepatocellular carcinoma. Cancer Res 1994; 54:4177-82.

9. Qin WX, Wan F, Sun FY, Zhang PP, Han LW, Huang Y, Jiang HQ, Zhao XT, He M, Ye Y, Cong WM, Wu MC, Zhang LS, Yang NW, Gu JR. Cloning and characterization of a novel gene (C17orf25) from the deletion region on chromosome 17p13.3 in hepatocelular carcinoma. Cell Res 2001; 11(3):209-16.

10. Xu J, De Zhu J, Ni M, Wan F, Gu JR. The ATF/CREB site is the key element for transcription of the human RNA methyltransferase like 1(RNMTL1) gene, a newly discovered 17p13.3 gene. Cell Res 2002; 12(3-4):77-97.

11. Guo JY, Xu J, Mao Q, Fu LL, Gu JR, De Zhu J. The promoter analysis of the human C17orf25 gene, a novel chromosome 17p13.3 gene. Cell Res 2002; 12(5-6):339-52.

12. Ching YP, Qi Z, Wang JH. Cloning of three novel neuronal CDK5 activator binding proteins. Gene 2000; 242:285-94.
13. Dhavan R, Tsai LH. A decade of CDK5. Nat Rev Mol Cell Biol 2001; 2:749-59.

14. Lew J, Huang QQ, Qi Z, Winkfein RJ, Aebersold R, Hunt T, Wang JH. A brain-specific activator of cyclin-dependent kinase 5. Nature 1994; 371:423-6.

15. Tsai LH, Delalle I, Caviness VS Jr, Chae T, Harlow E. p35 is a neural- specific regulatory subunit of cyclin-dependent kinase 5. Nature 1994; 371:419-23.

16. Chen J, Liu B, Liu Y, Han Y, Yu H, Zhang Y, Lu L, Zhen Y, Hui R. A novel gene IC53 stimulates ECV304 cell proliferation and is upregulated in failing heart. Biochem Biophys Res Commun 2002; 294:161-6.

17. Sambrook J, Fritsch E F, Maniatis T. Molecular Cloning: A Laboratory Manual 2nd ed. Cold Spring Harbor Laboratory Press, New York, 1989.

18. Patrick GN, Zukerberg L, Nikolic M, Monte S, Dikkes P, Tsai LH. Conversion of p35 to p25 deregulates CDK5 activity and promotes neurodegeneration. Nature 1999; 402:615-22.

19. Eisen JA. Phylogenomics: improving functional predictions for uncharacterized genes by evolutionary analysis. Genome Res 1998; 8:163-7. 